\title{
Punishment and Repentance
}

\author{
JOHN TASIOULAS
}

\section{Pluralism and the Limits of Theory}

In philosophical writings, the practice of punishment standardly features as a terrain over which comprehensive moral theories-in the main, versions of 'consequentialism' and 'deontology'-have fought a prolonged and inconclusive battle. The grip of this top-down model of the relationship between philosophical theory and punitive practice is so tenacious that even the most seemingly innocent concern with the 'consequences' of punishment is often read, if not as an endorsement of consequentialism, then at least as the registering of a consequentialist point. But to suppose that repentance or crime prevention, for example, are goods that punishment characteristically aims to secure is hardly to endorse the maximization of some value or set of values as the fundamental criterion of moral rightness. Equally, an appeal to desert or rights in the justification of punishment does not commit one to the deontological claim that these norms have a basis independent of human interests. This suggests that the prevalence of the top-down model may owe more to the inertia of established usage, or the temptations of over-intellectualization, than one might initially have supposed.

In any case, despite its promise of philosophical depth, the top-down model creates difficulties of its own. It commits one to the assumption that something like a 'theoretical' enterprise-one concerned to identify the ultimate criterion of moral rightness-is appropriate in ethics, and probably also that one or other of the existing moral theories is broadly correct. Like many others, I believe we should be sceptical about the ambitions of theory in ethics and that, in abandoning the idea of a master-criterion, we should instead embrace a form of pluralism that recognizes an irreducible plurality of ethical values that are prone to conflict in individual cases. Moreover, the conflicts among these values are not always rationally resolvable and, even where they are, they are not always resolvable by appeal to a pre-given principle nor always resolvable without remainder. If one finds this line of thought attractive, then one will not begin by making a gift to existing moral 


\section{John Tasioulas}

theories of the values and concerns invoked by ordinary, non-philosophical thought about punishment.

From this pluralist perspective, two other large-scale defects characteristic of theory-driven work on punishment come into view. First, there is a regimentation that leads to a reduction in both the number of values or principles relevant to the justification of punishment and also the potential for conflicts among them. In this vein, many theories aim to ground punishment in a single underlying consideration, such as the promotion of well-being or liberty, or compliance with norms of retributive desert or fair play, and so on. Some philosophers, of course, regard unity as counting strongly in favour of a theoretical approach and, indeed, as offering an important criterion for choosing between competing theories. Consider, for example, the pivotal role Braithwaite and Pettit assign to 'simplicity' in defending a consequentialist theory of punishment focussed on the promotion of the republican conception of liberty they call 'dominion'. ${ }^{1}$ A methodological consideration derived from the natural sciences, or at least from a favoured image of certain natural sciences, is here imported into the practical realm without encountering any resistance from Aristotelian strictures about the topic-relativity of the criteria of successful inquiry. But the simplicity of their theory doesn't mitigate the serious difficulties it faces in justifying intuitively compelling limits as to who may be punished and how severely one may punish them. ${ }^{2}$ Equally, the companion ideas that punishment should be responsive to what wrong-doers deserve, but that nonetheless mercy may counsel more lenient treatment in particular cases, also fade from view. Desert simply has no place in their framework, nor therefore does the idea of proportionality grounded in desert. And while they vigorously advocate 'mercy' for certain types of offenders, such as white-collar criminals, it emerges that this notion designates not a separate value, but rather the existence of a good consequentialist case for imposing a lighter sentence than that which is required or permitted by law. ${ }^{3}$ Similar observations could be made about standard retributivist theories insofar as they sideline mercy or considerations of prevention.

1 See J. Braithwaite and P. Pettit, Not Fust Deserts: A Republican Theory of Criminal Fustice (Oxford: OUP, 1990), 37-40.

2 See the criticism in A. von Hirsch, Censure and Sanctions (Oxford: OUP, 1993), 20-3.

3 Op. cit. note 1, 168, 190-6. 


\section{Punishment and Repentance}

Now, some proponents of theory construction try to address these pluralist concerns by advocating positions that combine elements from rival moral theories. Under this heading belongs the contention that the pursuit of a consequentialist justifying aim is to be constrained by norms prohibiting the punishment of the innocent or the disproportionate punishment of the guilty. Seemingly mixed theories, however, are often just more sophisticated versions of theories of the standard type, e.g. forms of ruleor multi-level consequentialism, and so ultimately succumb to objections of the kind that beset theories of the parent type. Thus, H.L.A. Hart's theory of punishment can be read as giving a multi-level consequentialist justification for the constraining norms. The prohibition on punishing the innocent, on this view, serves to maximize freedom by ensuring that individuals have advance notice of the sort of conduct that is liable to attract a punitive response from the state. ${ }^{4}$ But this interpretation, with its focus on crimes considered purely as legal wrongs, fails to address the concern that those innocent of any moral wrongdoing should not be punished.

In response, one might introduce a bona fide 'deontological' constraint prohibiting the punishment of the morally innocent on the grounds, taken to have irreducible significance, that they do not deserve to be punished. The resulting theory will be truly hybrid in character, assembled from the dismembered parts of incompatible general moral theories. But now a second defect is apparent, viz. that the theory arrived at is little better than an ad hoc compromise among radically disparate concerns. Proponents of hybrid theories can offer no coherent rationale for the principles they have combined-apart from the fact that they have been explicitly manufactured to yield results more attuned to our settled moral convictions-since one cannot, at the level of underlying theory, endorse both consequentialism and deontology. They thereby violate what, in a different context, has been called the 'no-shopping' principle. $^{5}$ The enhanced congruence with our

4 H.L.A. Hart, Punishment and Responsibility (Oxford: OUP, 1968), Ch.1.

5 '[W]e cannot pick and choose bits of one picture to put besides bits of another; the coherence of the pictures comes from their distinct histories [or, in the case of the principles in question here, from the wider theoretical setting in which they are embedded-JT]: this may be called the no-shopping principle.' S. Hampshire, Morality and Conflict (Blackwell, 1983), 148. 


\section{John Tasioulas}

intuitions that such theories achieve offers no real consolation, mainly because their incoherent character ensures that it doesn't go very deep. Thus, we should ordinarily think that no good reason exists to punish the innocent or to impose life sentences on violators of parking codes, not that any such pro tanto reason is defeated by the countervailing consideration represented by the relevant deontological principle. Hence the widely felt artificiality of consequentialist theories with deontological constraints bolted on: they are mere simulacra of the logic of punishment that fail to capture the spirit that animates the institution for those engaged with it.

At this point, one might reply that my objection to hybrid theories is really no objection, since the demand for coherence is misplaced. Instead, the long history of philosophical disputation about punishment teaches us that a cut-and-paste assembly of disparate principles is the best we can realistically hope for. ${ }^{6}$ But this is a devastatingly pessimistic conclusion, one to which we should acquiesce only with the utmost reluctance, since even its proponents acknowledge the 'deep-seated schizophrenia'7 to which it gives rise. This justifies us in seeking a more coherent account, which is what I attempt to develop in this paper. But how, it might be asked, can a pluralist hope to deflect the charge that he is proposing a bare conjunction of disparate elements? To begin with, as usually formulated, this objection gets much of its force from the implied contrast with the sort of account that top-down theories of punishment seek to deliver, i.e. a justification grounded in a single, underlying criterion of moral rightness. But why take this particularly stringent interpretation of coherence as authoritative, especially if there are strong reasons for resisting the enterprise of theory construction in the first place? Second, the pluralism I draw on is not a combination of 'deontological' and 'consequentialist' elements in the style of the leading hybrid theories. So it is not immediately open to the same formulation of the charge of arbitrariness that defeats them, i.e. that they rely on inconsistent general moral theories. It therefore holds out the prospect of an account of punishment that avoids both the one-sidedness of highly unified theories and the incoherence of their hybrid rivals.

6 A case for this approach is advanced in D. Wood, 'Retribution, Crime Reduction and Justification', Oxford Fournal of Legal Studies 22 (2002), 301-21.

7 Id., 304. 


\section{Punishment and Repentance}

But this does not yet dispose of the original objection. For it must be granted that a pluralistic account of punishment had better not simply present us with a jumble of distinct and conflicting considerations accompanied by the well-meaning but hollow instruction to exercise 'judgment' in discerning their practical import. Instead, it should tell us something about the nature of the operative values, how they relate to each other and why they have the salience they do for the justification of punishment. If this project could be carried through successfully, the integrity of the resulting account would stem from the way it articulates and makes sense of the values implicit in our practice of punishment and not from some pre-given general theoretical structure under which that practice is subsumed. So, in this paper, I proceed from a different starting-point: from a commitment to ethical pluralism, a scepticism about the claims of top-down theory and an insistence on the need for close scrutiny of legal punishment in order to identify the values that might justify it - not any existing practice, of course, but a feasible ideal version.

\section{Punishment as the Communication of Censure}

Punishment, I shall take it, is a practice that involves (a) the deliberate infliction of hard treatment, (b) on an alleged wrong-doer, (c) because of the alleged wrongness of their conduct, (d) by someone who claims the authority to inflict it for that reason, where (e) the hard treatment is intended to communicate to the wrong-doer justified censure for their wrong-doing. My concern in this paper will be specifically with legal punishment, i.e. punishment imposed by the state, standardly for violations of criminal laws. This formula is not usefully glossed as a 'definition' of punishment. This is partly because it is not intended to specify necessary and sufficient conditions for any activity that can, without linguistic impropriety, be so described. But partly also it is because philosophical 'definitions' often aspire to value-neutrality, purporting to take no stand on the value or point of the thing defined. It is perhaps in this spirit that we should understand the claim that component (e) is 'a statement of fact' about the nature of punishment, one compatible with conflicting accounts of its justifying purpose ${ }^{8}$ By contrast, my endorsement of the schema

8 A. Margalit, The Decent Society (Cambridge, Mass.: Harvard University Press, 1996), 269-270. 


\section{John Tasioulas}

given above is largely driven by the belief that, in a sense yet to be specified, (e) is the over-arching justifying 'point' of punishment. In other words, (e) is not just a condition for anything to count as punishment; instead, the fulfilment of the intention to which it refers is the justifying ground of punishment.

This last move amounts to an endorsement of the 'communicative theory' of punishment. As I understand it, this theory regards the communication of justified censure (through hard treatment) as the most general point of punishment, its General Justifying Aim in Hart's vocabulary. The primary addressee is the offender, although being essentially public in nature the censure is also communicated with certain third parties in mind, e.g. victims, other potential wrong-doers, law-enforcers and the wider community. The offender is intended to understand the censure conveyed by the criminal sanction, and hopefully to endorse the condemnation it expresses, to experience remorse and eventually come to repent of his wrong-doing by willingly undergoing the punishment meted out to him as a justified penance. As the ideal upshot of this process, the offender will go on to reform his future behaviour and attitudes so that he can achieve some kind of reconciliation with both his victim and the wider community whose norms he has violated.

If the communication of justified censure is the constitutive aim of punishment, then certain broad normative implications ensue. First of all, only those guilty of wrongdoing may properly be punished, and since they are being punished for their wrong, the censure visited on them, in the form of hard treatment, must be in some way proportionate in its severity to the wrong's seriousness. Justifications, excuses and mitigating factors that the alleged wrongdoer might be able to invoke, since they all bear on the existence or seriousness of a wrong, must be taken into account in determining whether to punish and, if so, how severely. It further follows that offenders are not appropriate objects of punishment to the extent that they are not fully responsible moral agents, whether at the time of their wrong-doing or that of sentencing. And they can fail to be so because they are unable to grasp the reasons behind the law's condemnation, e.g. that an act is wrong (defective in reason-recognition) or because they are unable to conform their decisions and conduct to any such recognition (defective in will). In other words, punishment is in order only if the offender is a morally responsible agent, capable of grasping and comporting themselves in line with the reasons against committing the wrongs in question. 


\section{Punishment and Repentance}

However, my view differs from other 'communicative' theories in one crucial respect. I conceive of the communication of justified censure as the formal, overarching justification of punishment. It is not a substantive justification in its own right, but the justifying aim internal to the practice of punishment that is given its substance-the nature and content of its message, as it were-by a diversity of values. The core value in this process is retributive justice, which justifies the infliction of hard treatment where, and to the extent to which, it is deserved as censure given the seriousness of the wrong committed (see section 3). But the formal end of condemnation can also encompass other values, such as mercy and crime prevention. What makes those values salient for punishment, and what provides the framework within which they can be related to each other in determining whether and how much to punish on any given occasion, is their relation to the formal justifying aim of communicating justified censure. Unlike most proponents of the communicative theory, therefore, I do not contend that punitive acts are justified exclusively by their communicating deserved censure. Instead, punishment is justified only if it is justified as censure for wrong-doing, where desert is a fundamental but not necessarily exhaustive, determinant of what is justified in this connection. Equally, because I regard blame as expressing that component of censure which is deserved for wrong-doing, my account refers to justified censure in an inclusive sense, rather than simply treating censure and blame as interchangeable. ${ }^{9}$

The basic motivation for the revised interpretation of the communicative theory is its ability to provide an integrated account of the significance that a diversity of values has for our punitive practices. In this way, it is hoped, an advance can be made on consequentialist and deontological theories of punishment that are insufficiently sensitive to value pluralism, or hybrid theories that

9 Cf. James Griffin's remarks on how 'utility' becomes a formal analysis of prudential value under the informed desire theory: 'Utility, on the old monistic interpretation, was the super, overarching substantive value. But now, 'utility'... is not to be seen as the single over-arching value, in fact not as a substantive value at all, but instead as a formal analysis of what it is for something to be prudentially valuable to some person. Therefore, utility will be related to substantive values such as pleasure or accomplishment or autonomy, not by being the dominant value that subsumes them, but by providing a way of understanding the notion '(prudentially) valuable' and hence the notions 'more valuable' and 'less valuable'.' J. Griffin, Well-Being: Its Meaning, Measurement and Moral Importance (Oxford: OUP, 1986), 31-2. 


\section{John Tasioulas}

fail to capture it in a coherent way. But a similar contrast can be drawn with the two most influential formulations of the communicative theory in recent years, those propounded by Andrew von Hirsch and Antony Duff. Thus, my version of the communicative account offers a more coherent position than von Hirsch's hybrid theory. The latter invokes the preventative function of punishment in order to justify the communication of censure through hard treatment. But immediately the danger of incoherence looms, since what is introduced as a supplement to censure threatens to subvert the fundamentally communicative character of his theory. I try to show, instead, that punishment should be justified more integrally, without relying on the preventative effect of sanctions in this way (see sections 3-4).

The contrast with Duff's theory, on the other hand, focuses on the latter's reductionism. For although Duff endorses a general pluralism in the domain of value, he also explicitly conceives of his theory as 'unified' under the aegis of retributive desert. ${ }^{10}$ I believe there is a deep tension between these two commitments, one that my account eliminates by abandoning the aspiration to substantive unity, replacing it with a formal unity that embraces pluralism without issuing in a mere collocation of disparate evaluative concerns. It should be noted, however, that in describing his theory as 'unitary', Duff officially means that it posits, if not a single goal or value that punishment serves, at least a coherent set thereof. So, he claims, retributive desert needs to be supplemented by future-directed concerns with repentance, reform and reconciliation. Thus stated, the desideratum of unity echoes the requirement of coherence that I suggested even a pluralistic theory must respect. However, as I shall go on to argue, Duff's theory fails to capture the full significance of repentance for our punitive practices, and the reason for this is that it remains unduly dominated by the idea of retributive desert (see section 5).

10 Thus he says: 'We should, in this as in other contexts, recognize an irreducible diversity of values'. R. A. Duff, Punishment, Communication, and Community (Oxford: OUP, 2001), p.47. But, in spite of the existence of a plurality of values, and of conflicts among them, he also says: 'a unitary theory is what I offer. Criminal punishment, I argue, should communicate to offenders the censure they deserve for their crimes and should aim through that communicative process to persuade them to repent those crimes, to try to reform themselves, and thus to reconcile themselves with those whom they wronged', ibid. xvii (my italics). 


\section{Punishment and Repentance}

\section{From Censure to the 'Ceremony of Pain'}

Any version of the communicative theory of punishment faces a seemingly devastating objection. In Bernard Williams' dramatic formulation of the problem, the lack of a suitable connection between censure and hard treatment prevents the communicative theory from being a theory of punishment at all. This is due to the centrality of component (a) in our understanding of what punishment is:

It is worth saying that a purely denunciatory theory of punishment seems not to be a theory of punishment, unless denunciation is in itself sufficiently painful to be the punishment. The idea that traditional, painful, punishments are simply denunciations is incoherent, because it does not explain, without begging the question, why denunciations have to take the form of what Nietzsche identified as the constant of punishment, "the ceremony of pain' ${ }^{11}$

This is a familiar objection, but I start from Williams' version of it because his seemingly ornamental reference to Nietzsche alerts us to the presence of two objections in this neighbourhood. The first, more radical objection, repudiates the very idea of moral blame as the appropriate, or deserved, response to moral guilt. In Nietzsche's version, the discourse of guilt and blame is of a piece with the 'slave morality' of good and evil, itself the product of resentment felt by the weak towards the strong, that it was Nietzsche's mission, and in some sense Williams' also as his follower, to transcend. If the practice of moral censure is vulnerable to a debunking explanation of this kind, then the very idea of justifying punishment as a form of moral censure will be a non-starter. And this will be so even if there are other grounds for inflicting hard treatment, e.g. to deter people from unwanted behaviour or to make a vivid display of one's power. Of course, few philosophers would endorse the radical aristocratic ideal underlying

11 B. Williams, 'Moral Responsibility and Political Freedom', Cambridge Law Fournal 56 (1997), 100. A classic earlier statement of the problem is H.L.A. Hart's: 'What is meant by the claim that the punishment of offenders is an appropriate way of expressing emphatic moral condemnation? The normal way in which moral condemnation is expressed is by words, and it is not clear, if denunciation is really what is required, why a solemn public statement of disapproval would not be the most 'appropriate' or 'emphatic' means of expressing this.' H.L.A. Hart, Law, Liberty, and Morality (Oxford: OUP, 1963), 66. 


\section{John Tasioulas}

Nietzsche's attack on the morality of blame. But what many of them do find congenial is the uncompromising naturalist standpoint from which it is launched. According to this, our understanding of human beings must be continuous with that which science has given us of the rest of nature. And one can readily see that this naturalism exerts great pressure on the picture of responsible human agency that concepts such as blame, guilt and desert appear to presuppose. One way it might do so is through the familiar problem of free will in a deterministic universe. Another way, stressed by Williams, is by pressing the idea that blame involves the fiction that certain ethical considerations constitute genuine, 'external' reasons for an agent that obtain irrespective of how that agent is motivated. ${ }^{12}$

The other, more common interpretation of the objection, allows that the practice of moral censure is in good standing. Even so, it alleges, there is a vast gulf between justified censure and justified punishment. This is because punishment, even if it communicates censure, does so through 'hard treatment', i.e. the infliction of something normally regarded as detrimental to one's genuine interests quite independently of its use as a vehicle of censure. But to damage people's interests in these ways is ordinarily regarded, in the absence of some special justification such as self-defence, as a grave moral wrong. So, the question remains: how can the communicative theory justify anything beyond purely symbolic forms of condemnation? If no justification is forthcoming, we will be forced to take seriously the unsettling Nietzschean hypothesis that the coupling of censure with pain in our punitive practices is the work of cruelty, a disposition to be gratified by the suffering of others, or else some other, equally debunking genealogical account, such as Foucault's appeal to the dominant forms of social and political power.

I distinguish between these two objections in order to focus on the second. Nietzsche's explanation of the morality of blame weaves them together, because he thinks that it is integral to the self-understanding of the latter that guilt provides a warrant for punishment. But most critics of the communicative theory would preserve the notion of moral guilt, and the idea that censure in the form of blame is the appropriate response to such guilt, whilst contesting the claim that the infliction of hard treatment can be justified simply as a way of communicating censure. And that, in

12 B. Williams, Ethics and the Limits of Philosophy (London: Fontana Press, 1985), 193. 


\section{Punishment and Repentance}

essence, is the second version of the objection. It is important, however, to guard against any surreptitious influence the first objection might exert under other, less openly radical, guises.

Now, one attempt to close the gap identified by the second objection appeals to convention. To communicate censure effectively, especially in a large pluralistic society, one must deploy conventional mechanisms that are widely and unambiguously understood to convey reprobation of an offender's conduct. The nature of these mechanisms will vary from one society to another, if only because natural languages so vary. In societies like ours, it will be said, various familiar modes of hard treatment are an integral aspect of the widely-understood conventional means for publicly condemning criminal wrong-doing, and it is this fact that justifies the imposition of sanctions. Hence, hard treatment is justified as the means of communicating censure in societies that share this convention. ${ }^{13}$ But, even when restricted in scope to cultures that resemble ours in this respect, the justification provided by this argument is too shallow. From the fact that some conventional means is necessary to convey censure, it does not follow that whichever particular means has been established is morally justified. Consider an analogy. The coming of age by younger members of a cultural group is a matter of profound significance, and there are good reasons for the group to adopt some widely-understood convention to mark this transition. But it does not follow that all such conventional markers, including genital mutilation or life-endangering trials of manhood, are morally acceptable. In the same way, it does not follow that the convention of condemning criminal wrong-doing by inflicting hard treatment on its perpetrators is justified. Indeed, given that there are purely symbolic means of effecting that communication, e.g. verbal reprimands or formal convictions, ${ }^{14}$ the original question persists: what makes the infliction of hard treatment a morally eligible conventional vehicle for communicating censure?

13 There is a suggestion, admittedly not unambiguous, of this train of thought in Feinberg, e.g. 'Given our conventions, of course, condemnation is expressed by hard treatment ...' J. Feinberg, 'The Expressive Function of Punishment', in R.A. Duff and D. Garland (eds.), A Reader on Punishment (Oxford: OUP, 1994), 89.

14 Not all of which will themselves be obviously morally acceptable, partly because some predominantly symbolic forms of condemnation shade over into hard treatment insofar as they subject the offender to certain painful forms of public humiliation or ridicule. 


\section{John Tasioulas}

The lesson to be drawn from the failure of the simple conventionalist strategy is that a justifying value must suitably underwrite the case for using hard treatment to convey reprobation. This is what the bare appeal to the punitive conventions of Western societies failed to yield. A distinctive feature of von Hirsch's theory is that it justifies the expression of censure through sanctions by invoking the preventative function of hard treatment. On this view, punishment is an effective conventional means of communicating reprobation. But, according to von Hirsch, nothing as onerous as the punishments meted out by the state can be justified purely as messages of blame. ${ }^{15}$ Instead, what makes it appropriate for sanctions, rather than formal censure, to play that role is the further fact that they discourage actual and potential wrong-doers from engaging in criminal conduct, e.g. through rehabilitation, deterrence, incapacitation and the reinforcement of law-abiding attitudes. On this 'two-pronged' justification for punishment, the moral reason to desist from crime grounded in the blameworthiness of the conduct, which is expressed by the reprobative function of the sanction, is backed up by a prudential reason created by the threat of hard treatment. In virtue of our susceptibility to the force of moral reasons, we are fit objects of censure, but given the temptations we can experience to rebel against those reasons, we are given a prudential reason to stiffen our resolve to be law-abiding.

The attractions of this theory are not to be underestimated. In contrast to pure preventative theories, offenders are addressed as responsible agents capable of moral deliberation, not simply subjected to what von Hirsch calls 'beast control'. Moreover, its qualified reliance on prevention ministers to two ideas that verge on the common-sensical: the Humean dictum that there is 'some particle of the dove kneaded into our frame, along with elements of the wolf and serpent'; ${ }^{16}$ and the widely-credited thought that prevention must surely have some fairly central role in the justification of punishment. Still, the theory remains open to serious objections. Perhaps the most fundamental is that censure is drastically down-graded within the theory, since it cannot by itself justify the most distinctive and potentially disturbing feature of punishment, i.e. the infliction of hard treatment. Instead, it is the appeal to prevention that provides the missing justification. But if this is the case, why shouldn't punishment, insofar as it involves hard treatment, count to that extent as 'beast control'? Moreover,

15 Op. cit. note 2, 13.

16 D. Hume, Essay Concerning the Principles of Morals, IX, I. 


\section{Punishment and Repentance}

what stops the concern with prevention from taking on a life of its own, so that it justifies the punishment of the innocent, or else justifies the disproportionate punishment of wrongdoers, in cases where the preventative pay-off is sufficiently great?

Of course, von Hirsch's response is that these objections fundamentally misconstrue the relationship between censure and prevention. The two elements are 'intertwined' in such a way that the former has primacy: 'It [the criminal sanction] is preferred to the purely symbolic response because of its supplementary role as disincentive. The preventive function thus operates only within a censuring framework.' ${ }^{17}$ But why, it might be asked, is this response anything more than an $a d$ hoc stipulation that prevention operates within the confines of justified censure? The problem is exacerbated by von Hirsch's tendency to refer to prevention as a consequentialist consideration, since consequentialism is a moral theory that claims to be comprehensive, and it is hardly obvious why, within that theory, the promotion of crime prevention should be constrained in this way. The threatened upshot is something like the underlying incoherence that bedevils hybrid theories in general.

Now, perhaps the 'primacy' of the censuring function can be vindicated on the basis of the overwhelming importance of addressing offenders as rational agents, susceptible to the force of moral reasons rather than mere threats. But even if we grant the latter constraint, there is a serious question about what it can amount to. One possibility (which I go on to endorse in section 4) is this: the communication of blame itself provides a sufficient reason to inflict a certain amount of hard treatment commensurate with the seriousness of the crime. Prevention is then a parasitic or dependent reason for inflicting the punishment that is deserved as blame, i.e. one that only exists once there is an independent, desert-based reason for inflicting a certain level of hard treatment. And, where it exists, it typically has the effect of strengthening the case for inflicting that level of hard treatment. But this cannot be what von Hirsch means, since he rejects the idea that censure per se can justify the infliction of hard treatment as a response to wrongdoing. Instead, his position seems to be the following. The criminal sanction expresses censure for wrong-doing, but the reason for preferring it to any other means of conveying censure is its preventative role. But given that it performs this dual role, there are limits as to who may be punished, i.e. only wrong-doers, since only they are appropriate objects of censure. And there are also

17 Op. cit. note 2, 14. 


\section{John Tasioulas}

limits to how severely one may punish them, since '[v]arying the relative amount of the deprivation ... will vary the degree of censure conveyed.' 18

But the inadequacy of this reply is shown by its stress on relative, as opposed to absolute, levels of material deprivation. Given that murder is a far graver crime than littering, one cannot impose the same sanction for both. But nothing in this argument disallows absolute levels of hard treatment that are intuitively grossly disproportionate, such as a year's imprisonment for littering providing that the penalty for murder is something like life imprisonment or death. Such punishments might be justified if they serve a preventative function, so long as the relative deprivation they inflict corresponds to the relative ranking of crimes on a scale of seriousness. ${ }^{19}$ This argument, incidentally, shows why von Hirsch could not overcome the objection by adopting the view that censure makes punishment a morally eligible response to certain kinds of wrong-doing, but that the level of hard treatment appropriate for those wrongs is determined by prevention.

The reply here will be that the situation just envisaged is excluded by the fact that the prudential threat posed by the draconian sanction would 'drown out' the rational force of the moral censure it was supposed to convey, thus failing to operate within a censuring framework. ${ }^{20}$ But everything now turns on how the 'drowning out' metaphor is to be elaborated. It cannot be taken in a merely empirical way, as referring to the relative motivational impact of the prudential threat, as opposed to the censure conveyed, on potential offenders. This would leave the severity of punishments hostage to the vagaries of human psychology, so that the appropriate sanction will be a function of a prospective criminal's relative timidity or toughness in the face of sanctions. Nor would appealing to a 'standard' psychological profile address the problem. This is because that very notion presupposes a standard that determines what is an appropriate response, one that has yet to be elaborated and defended. Instead, whether a punishment involves the deployment of a prudential disincentive

18 Op. cit. note 2, 17

19 In other words, the question here relates to what von Hirsch calls 'cardinal' scaling, i.e. what overall levels of punishment should be used to anchor the system of penalties, and not just 'ordinal' scaling, i.e. how severely crimes should be punished relative to each other.

20 Op. cit. note $2,42-3$. 


\section{Punishment and Repentance}

that swamps the censure it is intended to convey is a matter for moral judgment. More specifically, it appears that what is required is an assessment, at least within some range, of the quantum of hard treatment that is a fitting expression of justified censure for the wrong committed. And this means that, contrary to von Hirsch's argument, the concern with censure taken by itself must have implications for the absolute level of severity of the sanction that may be justly inflicted, independently of any concern with prevention.

There is another, admittedly more speculative, interpretation of von Hirsch's argument that seems to address the problem just rehearsed. According to this, sanctions are among the morally permissible ways of conveying censure, but it is their preventative function that singles them out as the obligatory way of doing so. So, it is permissible to serve the censuring function by inflicting sanctions proportionate in their severity to the wrong committed. But only the 'added value' of the preventative effects of doing so creates an obligation to respond to wrong-doing in that way. Yet even this strongly modified proposal is vulnerable to objections. One is that the justification of punishment, conceived as something there is typically a duty of justice to inflict, is placed on an extremely precarious footing, since evidence of the preventative effect of punishments is often meagre, especially regarding certain very serious crimes where the duty to punish seems most obviously to obtain. Secondly, it has not yet been shown why it is that hard treatment is indeed a morally eligible way of conveying censure, nor what constraints justified censure imposes on the level of deprivation that can be inflicted. Certainly, the criminal sanction can be used to convey censure, but that simply takes us back to the conventionalist strategy, and fails to show that it is morally permissible to use this conventional vehicle when there are purely formal alternatives to hand.

\section{Desert and Prevention}

The foregoing gives us sufficient cause to re-visit an avenue closed off by von Hirsch's theory. This is the possibility of regarding the infliction of hard treatment as an implication of justified censure itself. This means showing that the very same value that justifies censure in the first place also justifies its communication through 


\section{John Tasioulas}

hard treatment. On the formal account of the communicative theory that I sketched, that value is retributive desert. How would such an argument go?

The first thing to notice is that the formal account helps dispel a certain misconception that might give unwarranted force to the objection we have been considering. It is the mistaken idea that, on a communicative account, punishment is deserved because it is justified as censure. If this is the direction in which the relation between these concepts runs, then one might very well be mystified as to why censure need take the form of material deprivation. But, if anything, this gets things in precisely the reverse order. On the formal account, the censure conveyed by punishment is pro tanto justified because it embodies the blame that the wrongdoer deserves. The concept of retributive desert applies to agents who are morally responsible for their actions; and it embodies the norm that the appropriate, because deserved, response to wrongful actions is one of blame, which conveys to the wrong-doer a moral condemnation of their wrong-doing. ${ }^{21}$ Moreover, the degree of blame deserved must be proportionate to the gravity of the wrong committed. Without elaborating further, we can understand the gravity of the wrong as a complex, context-sensitive function of two factors: the harm the wrong inflicts or risks and the culpability exhibited by the offender in committing the wrong, i.e. the degree to which their will is identified with the wrong-doing.

In responding in this way to wrong-doers, we accord them an important form of respect. For implicit in the blaming response is a recognition of their moral status as responsible agents, beings who-unlike non-human animals, infants or the mentally handicapped-are able to grasp and comply with the reasons against performing the wrongful action. At the same time, however, blaming involves a withdrawal of full recognition from the wrong-doer, because their flouting of moral demands diminishes their status as a member of the relevant moral community. Communicating blame initiates a potential dialogue with them, one in which the correct response on their part is either to acknowledge the appropriateness of the blame, apologize, make reparation and repent of their wrong-doing or else to challenge (or have challenged on their behalf) the claims of responsibility, wrong-doing or culpability on which the blaming response is based. Another way of

21 For a discussion of the conceptual link between desert and doing, see J. R. Lucas, Responsibility (Oxford: OUP, 1993), Ch.7. 


\section{Punishment and Repentance}

putting the point about the respect accorded to offenders is to say, with Avishai Margalit, that it is a recognition of their capacity to repent:

Even if there are noticeable differences among people in their ability to change, they are deserving of respect for the very possibility of changing. Even the worst criminals are worthy of basic human respect because of the possibility that they may radically reevaluate their past lives and, if they are given the opportunity, may live the rest of their lives in a worthy manner ... Even though it is likely that she will continue living this way, this likelihood should not be turned into a presumption, because in principle an evildoer has the capacity to change and repent. This capacity implies that she deserves basic respect as a human being who should not be 'given up on', precisely because there is a chance, no matter how small, that she will repent. ${ }^{22}$

Notice Margalit's important observation that, beyond a certain threshold, basic respect does not vary with one's estimation of how likely someone is to govern themselves in the light of genuine reasons. More particularly, it does not vary with one's assessment of the likelihood that an offender will repent. What is crucial, here as elsewhere, about one's standing as an equal member of the moral and political community, is that a certain threshold capacity for rational self-governance is reached, not where one stands relative to others above that threshold. ${ }^{23}$

Now the question re-emerges: why is it appropriate for the deserved response to take the form of hard treatment, as opposed to formal condemnation? Our reply must begin by rejecting the stark distinction between censure and hard treatment the question assumes. Even purely formal censure constitutes hard treatment, since condemnation is meant to be experienced as unwelcome, a bringing up short of the wrongdoer, a drawing attention to, and denunciation of, his moral wrong-doing. Its unwelcome character

22 Op. cit. note 8, 70-75.

23 Cf. Jeremy Waldron's observation that the idea of basic equality - the basic respect due to all humans as being equal in status-is what Rawls called a 'range property': 'although there is a scale on which one could observe differences of degree, still once a range has been specified, we may use the binary property of being within the range, a property which is shared by something which is in the center of the range and also by something which is just above its lower threshold.' J. Waldron, God, Locke and Equality: Christian Foundations in Locke's Political Thought (Cambridge: CUP, 2002), 76-7. 


\section{John Tasioulas}

for the recipient finds its counterpart in the characteristic regret, felt by those charged with conveying censure, that it has to be inflicted. Indeed, it may even turn out on occasion that certain relatively anonymous and formal modes of material deprivation, such as monetary fines, constitute appreciably lighter treatment than some purely symbolic forms of condemnation, such as the naval institution of the 'captain's mast'. So, it is not as if we have to negotiate some enormous gulf between the justification of formal condemnation and that of hard treatment. Instead, the question needs to be re-cast: why must censure take the form of condemnation that involves hard treatment over and above the hard treatment already entailed by the most lenient means of communicating censure?

And here the answer must be that only punishment adequately conveys the blame the wrong-doer deserves. This captures a widespread and deeply ingrained judgment, viz. that the seriousness of the wrong committed warrants a blaming response that operates through the infliction of hard treatment, since only such a response adequately reflects the gravity of the wrong that has been committed. The thought here is not that only in this way can we demonstrate the sincerity of our condemnation, as if punishment were justified by a self-indulgent concern with personal moral purity transposed to the social level. Instead, punishment enables us properly to evince the sincerity of our condemnation precisely because it is what the offender deserves as blame for his conduct. To those who respond that to appeal to retributive desert is to invoke a mystery (and who proceed to insinuate that behind these incantations there lurks vengeance or some such motivation), it should be said that there is already enough on the table to distinguish retributive desert from vengeance. ${ }^{24}$ Nor is the sense that punishment for wrong-doing is justified worryingly confined to a class of potential 'punishers', an 'us' who inflict punishment contrasted with a 'them' who suffer it. Instead, just as our ordinary reluctance to injure others gives way in cases where punishment is judged to be deserved, so too the reactions of indignation and resentment normally exhibited by those subjected to hard

24 See the classic discussion of the contrast between retribution and revenge in R. Nozick, Philosophical Explanations (Oxford: OUP, 1981), 366-70. The former, unlike the latter, is always exacted for a wrong, can be inflicted by someone with no personal tie to the victim, is accompanied by no emotional tone beyond possibly pleasure in justice being done, and is subject to norms of proportionality and generality. 


\section{Punishment and Repentance}

treatment tend to recede when they share in that judgment. In some rare, yet not only intelligible but also admirable cases, the offender may actively crave their own punishment as a form of penance, but only on condition that it is deserved (see section 6).

Of course, one can still imagine those who will profess themselves mystified by the idea that a punitive response is deserved. To them one must eventually respond that retributive desert is a basic norm of justice, in that there is no other comparable norm in terms of which it can be fully justified or explained. One might be tempted to call one's knowledge of this norm an 'intuition', but for P.F. Strawson's caustic remark that 'an intuition of fittingness' is 'a pitiful intellectualist trinket for a philosopher to wear as a charm against the recognition of his own humanity'. ${ }^{25}$ However, if by 'intuition' we mean no more than a considered judgment on the part of someone with practical wisdom, then the temptation is one to which we may properly succumb. More specifically, the idea is that retributive desert forms an inextricable part of practices that deeply structure human life, practices which require no justification from a supposed rational standpoint independent of them and from which-Nietzsche, Williams and other sceptics nothwithstanding-there is no good reason to disengage. The correctness of this approach is confirmed by reflection on the striking failure of efforts either to eliminate retributive desert from our repertoire of ethical concepts or to reduce it to some other norm of justice, e.g. a norm of distributive justice, according to which the offender is to be punished because he took unfair advantage of those other members of society who have restricted their liberty by desisting from criminal wrongdoing. ${ }^{26}$

But similar problems of over-explanation plague some versions of the communicative theory, with the upshot that they lapse into error or vacuity or some combination of the two. An example of the former is John Lucas' contention that only through hard treatment can one translate the message of blame into a currency of values in which the offender is indisputably invested. This interpretation instrumentalizes retributive desert, making the justification of

25 P.F. Strawson, 'Freedom and Resentment', in Freedom and Resentment and Other Essays (London: Methuen, 1974), 24.

26 See, e.g. A. von Hirsch, Doing Fustice: The Choice of Punishment (New York: Hill and Wang, 1986) and J. Murphy, 'Marxism and Retribution', Philosophy and Public Affairs 2 (1973), 217-43. There is a helpful critique in Duff op. cit. note 10, 21-23 


\section{John Tasioulas}

punishment hinge on the value of the offender not just 'receiving' the message of condemnation, in the sense of grasping or being given the opportunity to grasp it, but of making him experience regret, if not remorse and repentance, for what he has done: 'The penalties annexed to his wrongdoing by the community make it be the case that the whole transaction was a bad buy from his point of view and by his own system of reckoning ...27 Such a view will have difficulty condemning the alarming strategy of piling punishment upon punishment until the condemnatory message has the desired effect on the offender's psyche. It is also ill-placed to avoid the conclusion that punishment should not be inflicted at all where the offender is an incorrigibly 'hard case' who will remain unshakeably convinced that the crime was well worth any punishment he might suffer. ${ }^{28}$ Alternatively, in cases where the offender is especially receptive to non-punitive forms of condemnation, it would seem to undercut the rationale for punishing him at all. More generally, this view is dangerously corrupting in making deserved punishment hostage to whatever potentially skewed value-system offenders have internalized, and in carrying the implication that if the offender is not punished it will be retrospectively shown that he had good reason to act as he did. ${ }^{29}$ Punishment must involve a material deprivation, a set back to objective interests, and must be capable of being understood as such by the offender. But its justification cannot be beholden to its likely impact on the offender's mental state given his system of values.

But the problems of over-explanation are not confined to instrumental interpretations of retributive justice. Robert Nozick contends that any such account needs to be supplemented by a 'non-teleological' norm, according to which the infliction of deserved punishment is right or good in itself independent of its

27 Op cit. note $21,98$.

28 Indeed, it will be vulnerable to the Nietzschean claim that punishment is, as a matter of fact, a massively counter-productive strategy, at least if its aim is to induce remorse and repentance: 'The real pang of conscience, precisely amongst criminals and convicts, is something extremely rare, prisons and gaols are not nurseries where this type of gnawing pang chooses to thrive ... On the whole, punishment makes men harder and colder, it concentrates, it sharpens the feeling of alienation; it strengthens the power to resist...' Nietzsche, On the Genealogy of Morals tr. C. Diethe (Cambridge: CUP, 1994), 58-9.

29 Op. cit. note 21, 101-2. 


\section{Punishment and Repentance}

consequences. Yet in its explication he advances the possibly vacuous idea that deserved punishment communicatively 'connects' the wrongdoer to correct values:

The wrongdoer has become disconnected from correct values, and the purpose of punishment is to (re)connect him. It is not that this connection is a desired further effect of punishment: the act of retributive punishment itself effects this connection ... Through punishment, we give the correct values, qua correct values, some significant effect in his life, willy-nilly linking him up to them ... There now is no puzzle about why we do not simply speak or telegram the ... message [of censure], without adding a punishment. The punishment is central-that is the way the correct values which he has flouted have a significant effect on his life ... as significant as his own flouting of correct values. ${ }^{30}$

That such a connection is effected by deserved punishment is in one sense undeniable: it is the wrong-doer's transgression of sound values that justifies certain others who adhere to those values in punishing him. In consequence, the punishment links the wrong-doer with those values through the medium of coercion. But the question here is one of relative explanatory priority. For it would seem that punishment only appropriately performs this mediating role if it is deserved by the wrong-doer; hence, the notion of 'connection' in play presupposes that of retributive desert and so cannot usefully be invoked to elucidate the latter. After all, as Nozick acknowledges, there are preferable ways of connecting to correct values, e.g. by acting rightly in the first instance or by repenting independently of punishment. ${ }^{31}$ What distinguishes the third way, presumably, is that it is deserved in light of the wrong that has been committed, and its severity must be proportionate to the gravity of that wrong (i.e. as 'significant as his own flouting of correct values'). If the idea of connection is not understood in terms of desert, but rather vice versa, the threatened upshot is a communicative version of lex talionis, as when Nozick suggests that for the most serious violations of important values, such as wilful

30 Op. cit. note 24, 374-7.

31 Ibid., 374-5. 


\section{John Tasioulas}

murder, only capital punishment is a response of equal magnitude. ${ }^{32}$ But this sort of view, quite apart from its disturbing implications, faces familiar difficulties, not least of which is a charge of mysteriousness akin to that which it was presumably invoked to dispel.

Interpreting retributive desert as an irreducible moral notion, in this way, does not mean that one must lapse into silence or brute insistence when that notion is challenged. I have already indicated the way in which retributive desert draws on other moral concepts and values, such as that of responsibility, wrong-doing and blame. Building on this, one can try to elaborate the more specific norms that structure the operation of desert in the justification of punishment. Here, I think, at least the following norms should be acknowledged: (i) that a finding of desert is typically the sine qua non of punishment, in that there is standardly no reason at all to punish someone in the absence of their deserving hard treatment for prior wrongdoing; (ii) considerations of desert can by themselves constitute a sufficient reason for the imposition of punishment and, in the case of the more serious forms of wrong-doing, an obligation-generating reason; and (iii) the amount of punishment deserved typically sets an upper limit on how severely someone may be punished, i.e. no more than is proportionate to the gravity of the wrong they have committed.

In addition, there are questions to be addressed about the conditions under which any agent has standing to inflict deserved punishment, just as there are additional questions concerning the conditions under which one has standing to communicate blame purely verbally to a wrong-doer. The legitimacy of the state, in particular, undertaking a punitive role turns on the fulfilment of at least the following four conditions: (i) the wrong-doing belongs to the class of wrongs that it is properly the state's business to concern itself with, especially by way of criminalization (the state interest condition); (ii) the offender does not belong to a class of citizens that has been victimized by the state in such a way as to undermine

32 Ibid. 377. However, Nozick proceeds to complicate his stance on capital punishment. The further requirement that the punisher be connected to the value of the person being punished-one that gives rise to the hope, embodied by teleological retributivism, that they may come to embrace correct values-tends to limit capital punishment to 'monstrous cases (e.g. Hitler) where there is no such value to which one might respond' (378f). In light of our previous discussion, Nozick is seeking to remedy the deficiencies of one principle by appealing to a further, equally problematic principle. 


\section{Punishment and Repentance}

the reasons its members have for abiding by otherwise just criminal laws (the non-victimization condition); (iii) wrong-doers have been given advanced notice through properly enacted laws that the wrong-doing in question is a punishable crime and of the kind and severity of sanction that may be inflicted for its violation (the rule of law condition); ${ }^{33}$ and (iv) the state is the most effective means of inflicting punishment where it is justified, without its attempt to do so incurring excessive costs (the efficacy condition).

Retributive desert not only operates within a network of concepts and values we already adhere to, but according it the status of an irreducible norm enables it to play a central role in justifying the institution of punishment. Indeed, the entitlement of retributive desert to that status is partly vindicated, retrospectively as it were, by the rest of the structure we can erect on it, once we conceive of desert as laying the groundwork for a communicative theory of punishment. ${ }^{34}$ Pursuing this line of thought, communicative theorists have emphasized the way in which the state's communication of blame through deserved punishment is constitutively related to a number of other valuable features of the institution of punishment: the opportunity it offers the wrong-doer to repent by undergoing his punishment as a penance; the emphatic dissociation of the community from the criminal's wrong that it makes possible; its vindication of the victim's status as a full member of the community by demonstrating how seriously it takes the wrong done to him; the reassurance it provides to other members of the community that certain forms of wrong-doing will not be tolerated; the public absolution it affords to those who might otherwise be wrongly accused or suspected of having committed the crime; and the message of encouragement and appreciation it sends to law-enforcement officials. But retributive desert, it must be stressed, can perform these valuable secondary functions only in light of the independent correctness of inflicting deserved hard treatment on wrong-doers as an appropriate way of communicating blame.

33 The fulfilment of this condition can not only affect standing to punish but also (in the case of mala prohibita) whether there is even a wrong that deserves punishment.

34 Thus, in cleaving to the idea that serious wrong-doing deserves a punitive response, we can echo Wittgenstein: 'I have arrived at the rock bottom of my convictions. And one might almost say that these foundation-walls are carried by the whole house.' L. Wittgenstein, $O n$ Certainty (Oxford: Blackwell, 1974), 248. 


\section{John Tasioulas}

A critic might retort that crime prevention is conspicuously absent from this list of valuable functions. Here we come to von Hirsch's second objection, in addition to the supposed gap between censure and sanction, to the idea that deserved censure can by itself warrant the infliction of hard treatment. 'The criminal law', he says, 'seems to have preventive features in its very design', 35 i.e. the threat that punishment annexed to criminal laws seems explicitly aimed at discouraging criminal conduct. The start of a reply is that we must not conflate the aim of the criminal law from the aim of punishment; indeed, the aims of criminal law are ideally achieved when no punishment needs to be inflicted. Still, von Hirsch's point can be reformulated as one about the aims of punishment with little loss of intuitive appeal. The second response is that the theory sketched so far can accommodate the preventative role of punishment without making the use of hard treatment depend on its preventative effect. In other words, we can advance a different version of von Hirsch's thesis that prevention operates within the framework of censure. This is the first interpretation of that thesis that I set aside in section 3 as inconsistent with his theory.

The communication of censure through hard treatment characteristically, but not inevitably, has a preventative effect insofar as: (i) emphatic condemnation of a wrong can sensitize people to the presence of reasons against committing it, thereby discourage them from doing so; and (ii) independently of whether they are led to grasp and comply with the reasons against wrong-doing, people are ordinarily also motivated to avoid the material deprivation inflicted by punishment. Both of these preventative effects, however, are ancillary to the infliction of deserved punishment, they are secured through its (threatened) infliction. Prevention is not characteristically appealed to as an independent consideration in such a way as to provide a justification for undeserved punishment. There are preventative reasons to punish, in other words, typically only if there are independent reasons of retributive desert to do so. Within the communicative theory, prevention belongs to the category of 'dependent reasons', i.e. 'reasons that are only reasons if there is another reason present as well'. ${ }^{36}$

Given this general connection between the infliction of deserved punishment and prevention, the latter assumes a multiple significance. First, it can strengthen the case for punishing in the

35 Op. cit. note 2, 12.

36 See J. Dancy, Ethics Without Principles (OUP, 2004), 19ff, which contains a useful discussion. 


\section{Punishment and Repentance}

first place, adding to the strictly desert-based reasons for inflicting blame through hard treatment. This enables us to contemplate the possibility that, if punishing has sufficiently low preventative value in any given instance, the desert-based reasons for inflicting it may be defeated by certain other considerations, e.g. the high costs of doing so. This differs from von Hirsch's position, which seems committed to not punishing where reasons of prevention do not obtain or are extremely weak (subject, perhaps, to systemic considerations of procedural fairness and ordinal scaling). Second, in so doing, it can help us decide questions of relative priority in the punishment of different offences, given the limited resources available to the criminal justice system. Third, considerations of prevention can help determine which agency has appropriate standing to punish, i.e. the institution best able to achieve the preventative function while respecting the constraints of desert and other relevant principles is the one that should do it. In the modern world, this usually singles out the state. Perhaps more importantly, considerations of prevention have a potentially significant role to play at the sentencing stage. The background to this role is the fact that desert may in a significant range of cases determine the just quantum of punishment only within a broad range. It is a mistake to think that there is, laid down in a Platonic code, the exact punishment that is proportionate to a given crime, even when the circumstances of the crime are fully specified. This indeterminacy does not render the idea that desert grounds punishment vacuous, something confirmed by our emphatic rejection of certain proposed sanctions as either grossly excessive or lenient. Then there is also the consideration of the ordinal ranking of punishments for different offences, whereby we have reason to ensure that the sanctions inflicted on wrongdoers correspond in their severity to the relative seriousness of their offences.

We can now see how preventative considerations can play a role in determining the amount and type of punishments to be inflicted in particular cases. Take a situation where a judge has discretion as to sentence. Retributive desert will constrain his judgment by determining a range of sanctions that vary in their severity. Given that he must impose a sentence within this range, considerations of prevention (both special and general) can be a reason for choosing a sanction at one level of severity rather than another. Of course, it is necessary for the judge to take into account considerations of procedural fairness (treating like cases alike) and those of ordinal scaling. But the key point is that prevention figures in the deliberation as a relevant consideration in fixing the sentence. 


\section{John Tasioulas}

Second, even in the case where the choice is between punishments of roughly equal severity, the type of punishment selected, e.g. imprisonment or a community service order, may be influenced by preventative considerations, either as they bear on the particular offender being punished or other potential offenders.

Yet someone might ask: why should not prevention break free of the framework just sketched, in which it operates under the aegis of desert? Why is it never justifiable, on preventative grounds, to adopt policies that deliberately punish the innocent or punish the guilty in excess of desert or at least run a very high risk of doing so? The answer is that this may well be permissible and perhaps even morally required in certain cases. But these will be marginal cases of punishment, a fact explained by the core justification of punishment that I have given. There are two types of case worth mentioning. First, there are certain situations where valuable social goals can only be achieved through general conformity with certain standards, and the requisite level of conformity is most reliably secured through the imposition of sanctions on non-conformers. In order to achieve the necessary degree of conformity sanctions may have to be imposed that exceed anything that would be validated by a pure concern with retributive desert. But the sorts of offences at issue here-e.g. illegal parking, littering and so on-belong to the administrative or regulatory end of criminal law. They do not figure among the offences that are the central concern of any adequate account of punishment, such as murder, rape and theft. Therefore, their marginal status according to the theory I have sketched is a back-handed confirmation of that theory.

Cases of dire emergency are the second example. In time of war or in the face of a serious terrorist threat, we may have no alternative but to court a high risk of punishing the innocent or punishing the guilty grossly in excess of desert, for only in this way can many thousands of lives be saved. ${ }^{37}$ But now we are overriding the concerns that fundamentally structure the institution of punishment, as is shown by the fact that people treated in these ways typically have a claim to compensation once the state of emergency has passed. And the more that the operation of the institution of punishment is organized around these extraneous concerns, the more its distinctive character as an institution

37 One needs to tread extremely carefully in admitting this possibility. For a powerful cautionary argument, see S. Lovibond, 'Absolute Prohibitions without Divine Promises', in A. O'Hear (ed.), Modern Moral Philosophy (Cambridge: CUP, 2004), 141-158. 


\section{Punishment and Repentance}

grounded in the communication of moral censure is subverted. This illustrates a familiar phenomenon: the tendency of unpropitious circumstances to hinder the realization of goods internal to certain practices and institutions. Here we confront the fact that the logic of punishment does not exhaust the logic of all-thingsconsidered moral deliberation, even when the topic of our deliberation is the infliction of hard treatment for supposed wrong-doing.

With respect to both examples, it will ordinarily be the case that the permissibility of overriding the demands of desert is partly dependent on fairly strict compliance with the rule of law condition; this is an especially important consideration in cases of the first sort. In this way, the state's intrusion on personal autonomy is more limited than it otherwise would be, despite the cost in retributive justice.

\section{The Significance of Repentance}

I turn now to one of the moral notions whose significance for punishment is best elucidated within the communicative theory developed so far. The notion is that of repentance, understood as a cluster of responses on the offender's part, including: the experience of guilt or remorse in response to his wrong-doing; a willingness to make apologetic reparation to his victim and the wider community; a ready acceptance of justly inflicted punishment; a sincere resolution to alter his attitudes and behaviour; and, ideally, as the upshot of this process, a genuinely reformed character or amended way of life. I shall be particularly concerned with the proper treatment of the already repentant offender. And my claim will be that the formal version of the communicative theory enables us to give an account of the dual significance of repentance under the aspects of both justice and mercy. In this way, it is preferable to the leading versions of the theory that are unified under the aegis of retributive desert and consequently offer a mono-dimensional account of repentance.

Now, of course, some philosophers deny that repentance has any significance whatever for punishment. J.D. Mabbott held this view, but only because for him punishment is justified for the breach of legal (or similar, institution-dependent) rules, not for moral wrong-doing as such. Only God, he thought, has the requisite standing to punish moral wrong-doers. Repentance, however, is an appropriate response to moral wrong-doing, so its occurrence has 


\section{John Tasioulas}

no bearing on whether to punish or how much to punish within Mabbott's legalistic theory. ${ }^{38}$ But we have already endorsed the idea that punishment is justified only for moral wrong-doing: it is the wrongfulness of the offender's conduct that renders intelligible the moral condemnation communicated by punishment, even if the existence of the wrong is in some cases a creature of the law criminalizing the conduct in question (mala prohibita). And within the putatively dialogical structure of the communicative theory, repentance is the hoped-for, or at any rate the ideal, response on the wrong-doer's part.

It follows that adherents of the communicative theory need to face up to the question: what significance should be ascribed to repentance that has already occurred, before punishment has been (fully) imposed? To sharpen the discussion, I assume the offender is already fully repentant at the sentencing stage, or at some stage well before the completion of his sentence. Moreover, I abstract from the notorious difficulties involved in judging the authenticity of repentance in individual cases, including the moral constraints that inhibit a liberal state from certain forms of intrusion into the lives and psyches of its citizens. I also bracket the important question of how repentance can be made publicly credible, so that official leniency on the grounds of repentance does not encourage a cynicism among the wider community that subverts the condemnatory function of punishment.

In addressing our question, leading proponents of the communicative theory, even those who accord repentance a central role, tend to divide into two opposing camps. According to the Lenient, as I shall call them, we have a good reason not to punish the already repentant offender, or anyway we have good reason to punish him less severely than would have been justified but for his repentance. And this is because his repentance alters our assessment of how much punishment he deserves - he deserves to be punished less by virtue of his subsequent repentance. This sort of view comes easiest to those who adopt the teleological interpretation of retributive desert mentioned previously (section 4). If the

38 'Repentance is the reaction morally appropriate to moral wrong and punishment added to remorse is an unnecessary evil. But if punishment is associated with law-breaking and not with moral evil, the punisher is not entitled to consider whether the criminal is penitent any more than he may consider whether the law is good.' J. D. Mabbott, 'Punishment', Mind 48 (1939), 152-67, 157. He takes it as an advantage of his theory that it explains how we can reconcile punishment with repentance. 


\section{Punishment and Repentance}

punishment is deserved as a means to elicit an appropriate response-minimally regret, ideally repentance-on the part of the offender given his original, unregenerate system of values, and if the offender's values have already radically shifted in the desired direction through his repentance, then the rationale for imposing the original amount of punishment is correspondingly eliminated or diminished. The point of punishment has, to that extent, been pre-empted by the offender's repentant response to his wrongdoing.

The Lenient view is endorsed by Nozick. Since he believes that at least part of the justification for punishment derives from a teleological interpretation of the retributive norm, it follows that the repentant offender deserves to be punished less severely than an otherwise identical unrepenant offender:

Consider next a person who (before capture) sincerely repents of his wrongful act and, on his own, makes amends to the victims, goes off and does extraordinary deeds-works in a leper colony or whatever-from a desire to add good to the world. Does such a person now deserve to be punished, should he be punished? Again, retributivists feel uneasy in saying so ... Our theory accounts for this; since the person already is connected up with correct values qua correct values, since these already have a significant effect in his life, there is nothing for punishment to do. The further consequence the teleological retributivist hopes for is present, the link to be effected already holds. It is important, though, that the link with correct values make a significant alteration in his life, in what his life otherwise would have been, that it alter his life significantly, and negatively according to his previous view. ${ }^{39}$

A similar position appears to be endorsed by Lucas. According to him, in cases of repentance, 'mercy' operates in 'the interplay between the imputed original system of values of the wrongdoer and the actual system of values of the genuinely reformed character' ${ }^{40}$ The thought here seems to be that the offender deserves more lenient treatment in light of his repentance, because his just deserts are determined, in significant part, by what it would take to elicit the appropriate response, and now that a response of that kind is already forthcoming, a lesser punishment (or perhaps no punishment) is needed to elicit it.

39 Op. cit. note 24, 385 .

40 Op. cit. note $21,111$. 


\section{John Tasioulas}

Whatever one may think of the Lenient conclusion, we have already found cause to resist the key premise on which it rests: the instrumental interpretation of the retributive norm. Moreover, the account we have developed of retributive desert is at odds with giving repentance this desert-reducing role. To begin with, desert is action-focussed, whereas repentance, in its fullest sense, is best understood as a thoroughgoing change of heart, one not straightforwardly reducible to the performance of any action or series of actions. More importantly, retributive desert is backwardlooking: it focuses on a past wrong-doing, and the hard treatment that is deserved communicates blame for that wrong-doing. The amount of punishment deserved depends upon the gravity of the wrong; in particular, the culpability it manifests and the harm it risks. The gravity of the wrong is not influenced by anything that takes place subsequent to the wrong-doing, such as the offender's profound repentance. Of course, whether punishment can be properly inflicted is conditional upon the offender remaining a responsible moral agent, but this does not modify our assessment of what punishment he deserves. The main exception to this principle, which only serves to confirm it, is the situation in which the offender's repentance occurs immediately upon the commission of the wrongful act and in such a way that it influences our estimation of the latter's very nature. ${ }^{41}$ In this sort of case-for instance, where the offender is immediately appalled by what he has done, apologizes and seeks to make amends to the victim, and without delay turns himself in to the authorities despite having a perfectly good opportunity to evade capture-repentance is a factor mitigating culpability. We construe the action as a lapse or aberration, a succumbing to temptation or the pressures of the moment, rather than the product of a settled determination to do wrong.

To these thoughts one may add another. It is normally taken to be constitutive of repentance that the offender acknowledges that they deserve to be punished and, moreover, that they are willing to undergo the punishment they deserve. Hence the role of punishment as a penance that enables the offender to give expression to his sincere repentance. Truly repentant offenders do not regard their repentance as in any way cancelling or diminishing

41 Op. cit. note 10, 120-121. See also J. Murphy, 'Repentance, Punishment and Mercy', in A. Etzioni and D.E. Carney (eds.), Repentance: A Comparative Perspective (Rowman and Littlefield, 1977), 150. 


\section{Punishment and Repentance}

the fact that they deserve to be punished; this partly explains why such an offender might voluntarily turn himself in to the authorities. Of course, this belief might be interpreted as an understandable, even in some ways admirable, masochistic confusion brought on by the offender's desire to ease the pangs of a guilty conscience. But the idea that repentance characteristically manifests itself in a wholehearted acknowledgment that punishment is deserved, combined with a readiness to submit to it, is firmly entrenched in common-sense and therefore not easily dismissed as illusory from the vantage point of philosophical theory.

Consider a possible reply by the defender of the Lenient view, one that does not implicate the instrumental account of desert. Repentance, he might say, does bear directly on deserved punishment, because a person who has already been punished for their wrong does not deserve to be punished for it again, and we can interpret the process of repentance he undergoes as a form of self-inflicted punishment. In appealing to the concept of selfpunishment, however, this 'double jeopardy' response distorts both the concept of punishment and that of repentance. First of all, punishment is paradigmatically administered by a third party authorized to inflict it. This is not a devastating objection to the response. After all, it seems perfectly reasonable to say that if a vigilante group 'punishes' an offender by beating him severely, then he deserves less punishment from the state than would otherwise have been the case, perhaps even no punishment at all. If we are willing to allow this extension of the notion of punishment, then why not a further extension to the case of self-punishment?

But there is a second difficulty. In cases where we think someone no longer deserves to be punished, because they have been informally 'punished enough' already, some hard treatment is normally involved over and above the feelings of guilt and remorse that we hope the offender will come to experience. But genuine repentance need not always involve anything remotely analogous to 'hard treatment'. Sometimes it may do so, as perhaps in Nozick's example of working in a leper colony. But even this is not punitive hard treatment in any standard sense. To begin with, it is not necessarily publicly undertaken as a penance, as a forceful and clearly understood way of apologizing to the victim and the broader community. Moreover, many undertake this sort of work voluntarily, and their doing so successfully enhances greatly the value of their lives. Doing the work can manifest, both to the repentant offender and others, the profound change in his values. Hard 


\section{John Tasioulas}

treatment, by contrast, would consist in being coerced to work in a leper colony, whether one wanted to or not; it would be a curtailment of one's autonomy and liberty. But there are also cases of genuine repentance that do not involve undergoing anything remotely resembling a penance. Consider, for instance, the petty thief who comes to a sudden realization of the wrongfulness of his life of crime through a moral or religious conversion, then settles down to a perfectly decent family life, caring for his hitherto neglected wife and children. Of course, the realization will be a painful one, but again it is stretching things unduly to treat his feelings of guilt and remorse as a punishment.

We seem forced, then, to embrace a Strict response to our original question, one that accords no punishment-reducing significance to repentance. Such a response is advocated by Duff, persuasively rebutting in the process the accusation that a communicative theory that lays stress on repentance as an aim of punishment is automatically committed to the Lenient View. ${ }^{42}$ Repentance does indeed have great significance within the theory, but it is tied constitutively, not merely instrumentally, to deserved punishment. So far as Duff's version of the communicative theory of punishment is concerned, it is true that punishment should typically help induce repentance in the offender. It can do this by providing a structure within which offenders are directed to focus their attention on their wrong-doing in a way conducive to remorse, apology and self-reform. But even more importantly, punishment has a constitutive link with repentance: the offender is given the opportunity to communicate his repentance in a forceful and public manner precisely by undergoing the deserved punishment in the appropriate spirit, as a deserved punishment for wrongdoing. Deserved hard treatment thus becomes an integral part of repentance: it acts as a penance through which the offender can make a forceful, public apology to his victim and the wider community for the wrong he has committed. ${ }^{43}$ Any repentance exhibited independently of the punitive process is irrelevant within

42 Op. cit. note 10, 118-121. The charge is made by von Hirsch, op. cit. note 2, 10: von Hirsch has an instrumental justification for the use of hard treatment to convey censure (i.e. prevention), and he incorrectly assumes that Duff too must have such an account (one geared to the eliciting of a penitent understanding of the offender's wrong).

43 As Duff puts it: 'The point here is not just an evidential one-that undertaking penance gives others stronger evidence of sincere repentance than merely verbal confession and apology could give ... It is rather that undertaking a penance, giving this outward and materially burdensome 


\section{Punishment and Repentance}

the theory, since it does not bear on what the offender deserves as a penance. It is, therefore, not a ground for revising downwards our assessment of the level of punishment that is deserved. Moreover, where the offender has failed to repent, even after having been punished, there is no basis for concluding that he deserves to be punished further, until he does repent.

If we must choose between the Lenient and the Strict responses, the latter is preferable. It preserves the integrity of the retributive norm by positing a constitutive, rather than a merely instrumental, relationship between desert and repentance. Punishment enables the offender to repent precisely through undergoing the deserved punishment as a penance; repentance is not simply something distinct from the deserved punishment that the latter is supposed to 'bring about'. And, in preserving the integrity of the retributive norm in this way, it makes sense of the idea that the repentant offender acknowledges and willingly submits to the deserved punishment. But, of course, it is difficult to shake off the feeling that there is more to the Lenient response than misguided sentimentality, that repentance has a significance beyond that which the Strict are prepared to countenance. This is why both Lucas and Nozick understandably take the recommendation of leniency issued by their theories to reflect favourably on the latter. My contention is that the formal version of the communicative theory enables us to take the measure of the further significance of repentance without compromising the integrity of the retributive norm. This is because the formal theory does not equate justified punishment with deserved punishment, so that repentance can have a bearing on justified punishment independently of any impact on judgments of desert. To make room for the full normative implications of repentance then, we have to dislodge the assumption that apparently unites both the Lenient and the Strict: that insofar as repentance bears on the justification of punishment, it does so exclusively by influencing our assessment of whether, and if so how much, punishment is deserved.

So understood, the formal theory enables us to redeem the venerable idea that repentance is a ground for mercy, but mercy

expression to the painfully burdensome recognition of one's own wrongdoing, is a way of taking the matter seriously; it part constitutes the repentant sinner's earnest repentance.' R.A. Duff, 'Penance, punishment and the limits of community', Punishment and Society 5 (2003), 295-312, 299. See also op. cit. note 10, 119. 


\section{John Tasioulas}

conceived now as a value that is distinct from the considerations of justice captured by the retributive norm of desert. Mercy is a source of pro tanto reasons, defeasible in the context of an all-things-considered judgment, for punishing the offender less severely than they deserve. It is not a source of reasons showing that they deserve to be punished less severely. This differs from conceptions of mercy, like Lucas', which operate within the logic of desert. Insofar as there are leniency-justifying factors internal to desert, they are best understood as mitigating considerations of justice, not of mercy. Retributive desert falls within the domain of justice, for two main reasons: it embodies a norm of proportionality that operates interpersonally (how much $\mathrm{X}$ deserves by way of punishment must be proportionate to the gravity of the wrong he committed against Y) and, perhaps more importantly, it is tightly bound up with moral rights (which are standardly taken to demarcate the domain of justice). The linkage of retributive desert with moral rights is threefold: (i) it is only wrongful acts that deserve to be punished, and the paradigm instances of punishable wrongs are those that involve the violation by the wrong-doer of the victim's rights; (ii) the offender has a right not to be punished beyond the upper limit of severity mandated by considerations of desert; and (iii) the community as a whole, even if not each individual victim, has a (collective) right to punish those who commit certain wrongs. I defer until later the reasons why we should shrink from the Hegelian claim that offenders have a right to be punished.

Mercy, by contrast, embraces reasons for leniency that arise out of a charitable concern with the well-being of the offender, in particular, the compassion we rightly feel towards him as a potential recipient of deserved punishment given various other facts about his life and circumstances whose salience is not captured by the retributive norm. ${ }^{44}$ Unlike many judgments of justice, there is no implication here of some norm of proportionality that operates interpersonally, balancing benefits and burdens across individuals. Moreover, offenders do not have a right to mercy, not even in cases where those dispensing punishment have a duty to be merciful, one set against their duty of justice to inflict a deserved punishment. If such a right existed, it would mean that the duty to show mercy was grounded exclusively in the interests of the offender in being

44 For an extended account, see J. Tasioulas, 'Mercy', Proceedings of the Aristotelian Society CIII (2003), 101-132. 


\section{Punishment and Repentance}

shown mercy. ${ }^{45}$ This is implausible on two grounds. The first is that the reason to grant mercy is always confronted by an opposing, typically duty-generating reason, grounded in retributive justice, to impose the deserved punishment. After all, like reasons of prevention, those of mercy also have the status of 'dependent reasons' within the communicative theory: they exist only if reasons (of retributive desert) to punish the offender also exist. The latter reason, in the great run of cases, may defeat or counterbalance the reasons of mercy, thus undermining the claim that the offender's interest is by itself sufficient to impose a duty on sentencing authorities to be merciful. The second ground is the difficulty of reliably assessing whether an offender has genuinely repented-a difficulty exacerbated not only by the offender's temptation to succumb to self-interest or self-deception but also by the operation of norms prohibiting a liberal state from intruding in certain ways on the lives of its citizens-with the consequent risk that mercy might be granted on a spurious basis. In light of these two points, one should admit that the duty to show mercy rests in crucial part also on the great common good of living in a humane society in which, among other things, compassion for repentant wrong-doers is able to manifest itself in punishments that are less severe than those that might be justly imposed as deserved. But, because this duty does not have its origins in the interests of wrong-doers considered in themselves, an interest-based account of rights cannot validate a right to mercy.

Once repentance is conceived as a potential ground for mercy, we can make sense of the attitude of the already repentant offender who nevertheless enters a plea for leniency, i.e. for punishment less than he deserves. Nothing about his repentant state alters the fact that he deserves to be punished nor how much punishment he deserves. Nor does it affect his acceptance of these judgments of desert. But the retributive norm is not exhaustive of the considerations that bear on justified punishment within the pluralistic version of the communicative theory. Repentance is a countervailing consideration of mercy that, he believes, either defeats to some extent, or is incommensurable with, the considerations of justice that fall under the retributive norm. In the latter case, failure to show him mercy does not go against reason, so there is no justification for the offender to feel aggrieved, as opposed to disappointed. In the former case, he may indeed feel aggrieved,

45 At least on a plausible, interest-based account of rights, e.g. J. Raz, The Morality of Freedom (Oxford: OUP, 1986), ch.7. 


\section{John Tasioulas}

insofar as the sentencing authority has failed to comply fully with reason. But there will be a stark difference between this sort of case and the one to which the Lenient attempted to assimilate cases where repentance was accorded no significance, i.e. those in which the offender is punished in excess of what he deserves. When mercy is not granted, the offender may not conclude that his rights have been transgressed, in the sense that some duty arising exclusively from his interest has not been respected. In both cases the offender admits that he deserves to be punished, and that the extent of punishment he deserves is unaffected by his subsequent repentance. But he brings to the attention of the authorities additional considerations not encompassed by retributive justice. The presence of the distinct and conflicting considerations of justice and mercy enables us, within a pluralistic framework, to preserve the integrity of the retributive norm, and yet also to explain the sense that something integral to the punitive process genuinely speaks against the untempered infliction of the deserved punishment.

Notice, finally, a potentially awkward consequence of the Strict view. If the Strict claim that the only notion of repentance we should acknowledge is one that necessarily involves undergoing the deserved punishment as a penance, then they will have difficulty avoiding the inference that offenders have a right to legal punishment, at least those who perpetrate serious crimes. This is because of the overriding importance that will then attach to punishment from the offender's perspective: it will become the only means of genuine repentance, hence his only means of re-integrating into the community whose law he has violated. This understanding of the importance of punishment, and the suggestion that a right to atonement through punishment is entailed by it, is eloquently expressed by Simone Weil:

Punishment is a vital need of the human soul ... By committing crime, a man places himself, on his own accord, outside the chain of eternal obligations which bind every human being to every other one. Punishment alone can weld him back again; fully so, if accompanied by consent on his part; otherwise only partially so. Just as the only way of showing respect for somebody suffering from hunger is to give him something to eat, so the only way of showing respect for somebody who has placed himself outside 


\section{Punishment and Repentance}

the law is to reinstate him inside the law by subjecting him to the punishment ordained by the law. ${ }^{46}$

But it is far from obvious that the offender's interest in being punished is, taken by itself, sufficient to impose a duty on us to do so. Would a victim of assault who decides not to press charges, perhaps out of forgiveness or simply a desire to bring a distasteful episode to an end, violate (even permissibly) the rights of their attacker? Or could one reasonably level a similar allegation against the Japanese criminal justice system, which is supposedly geared towards eliciting repentance on the part of offenders precisely as an alternative to the infliction of punishment? ${ }^{47}$ We can explain why no such right exists by pointing out that a penance need not be essential to repentance, and that even where it is essential, legal punishment is not an indispensable component of the process of repentance that leads to atonement. Added to this is the fact that there are always serious, countervailing costs imposed on others in the legitimate infliction of punishment. The duty to punish cannot, therefore, derive exclusively from the offender's interest in being punished. Still, we can preserve the grain of truth in the Hegel/Weil thesis by speaking instead of a right to repentance that does not automatically carry with it the right to be punished. ${ }^{48}$

46 Simone Weil, The Need for Roots (London: Routledge, 1996), 20. See also the classic statement of Hegel, The Philosophy of Right, tr. T.M. Knox (Oxford: OUP, 1967), 71. The right is seemingly endorsed by Duff, 'Penance, punishment and the limits of community', 303 and by John Skorupski in, 'Freedom, Morality, and Recognition: Some Theses of Kant and Hegel', Ethical Explorations (Oxford: OUP, 1999), although the latter's focus is on punishment as a moral, rather than a specifically legal, concept.

47 See the discussion in J. Braithwaite, Crime, Shame and Reintegration (Cambridge: CUP, 1989), ch.4.

48 Focussing on repentance through legal punishment can also lead us to ignore the need to provide means for showing repentance outside of the context of legal punishment, especially for those who do not accept their punishment (while undergoing it) as a penance, see R. Wuthnow, 'Repentance in Criminal Procedure: The Ritual Affirmation of Community', in A. Etzioni and D.E. Carney (eds.), Repentance: A Comparative Perspective (Rowman and Littleheld: Lanham, Maryland, 1997). The importance of repentance achieved other than through legal punishment-specifically, through the transformative power of personal love-is, I think, a major theme of Dostoevsky's Crime and Punishment. See, in this connexion, some illuminating remarks of Griffin's in op. cit. note $9,267-8$. 


\section{John Tasioulas}

Now, of course, the Strict need not go so far as to deny the possibility of repentance without (legal) punishment. They can simply say that, when it comes to the justification of legal punishment, such repentance has no significance in determining the offender's sentence. This seems a strained, but not inconsistent, position. The idea would be that repentance other than through punishment is an extraneous consideration, one that does not fit into the communicative theory of punishment. Therefore, the argument goes, antecedent repentance is not a relevant consideration in determining whether to punish or how much punishment to inflict. Indeed, the Strict might even concede that cases might arise in which, all-things-considered, repentance may properly lead us to punish less severely. But this will be akin to the situations where a sufficiently large deterrence pay-off justifies us in subverting the communicative logic internal to punishment. So the final challenge facing us is to show that repentance as a basis for mercy is integral to the communicative theory, rather than some outlying consideration that can at best override it.

\section{Antecedent Repentance within the Communicative Theory}

The communicative theory, let us recall, is a formal account of the theory of punishment. It regards the communication of justified censure to the offender as the primary aim of punishment. This presupposes that the offender is a rational agent, one with the capacity to grasp and comply with moral demands. In this way, punishment manifests a basic respect for the offender as a responsible moral agent. Second, the communicative process focusses not on the offender's character, but on his conduct. It is a process initiated by and centrally concerned with his wrong-doing, and justified censure is first and most fundamentally determined by the blame the offender deserves for the wrong he has committed. The hoped for upshot of this process is that the offender should come to share in the condemnation of his wrong-doing, to repent of his wrong-doing by undergoing the punishment as a penance and to alter his future behaviour so as to be fully reconciled with the community from which his wrong-doing has alienated him. How does repentance antecedent to punishment fit into this structure?

There are two observations I want to make in response to the challenge issued at the end of section 5. The first starts from the fact that the communicative process focuses on the wrong that the 


\section{Punishment and Repentance}

offender has committed. But if so, it may be asked, how can repentance, which may occur long after the wrongful act and concerns not any act or series of acts, but rather the offender's altered mode of being, fit into the process? The answer, I think, is that in penal communication it is perfectly legitimate to widen one's field of vision beyond the wrongful act-to take account of the nature of the agent and his broader circumstances-provided the facts about the agent and his life that come into view meet two further conditions. First, taking them into account must redound to the offender's benefit, i.e. the role of retributive desert as the fundamental and characteristically exclusive basis for condemnation is honoured, with no additional condemnation being incurred because of the offender's flawed character. In this way, the problems that beset versions of 'character retributivism' are avoided. Second, the further facts must have a requisite connection to the wrongful act to make them bear on justified censure for wrong-doing. In this way, the offender's wrong-doing remains the ultimate focus in the process of penal communication.

In the case of antecedent repentance, both conditions are satisfied, but it is worth spelling out how this is so in the case of the second condition. Repentance takes as its object the wrongful act one has committed; one cannot, for example, repent of aspects of one's appearance or personality that are not, in the same way, fairly amenable to the control of one's will. Moreover, the wrong the offender has committed is not merely antecedent to, or even part of the causal lead-up to, his repentance; instead, repenting is the correct personal response to one's wrong-doing. As Nozick stresses, the repentant offender rationally responds to the wrong-doing qua wrongful behaviour; repentance is not simply a personal transformation unmediated by this sort of rational response to his wrongful act considered as such. ${ }^{49}$ It would not be genuine repentance, for example, if the offender's transformation were simply triggered by a desire to avoid social opprobrium caused by his wrong-doing. So, when the offender pleads for mercy on the grounds of repentance, he remains a participant in a two-way communicative process that has wrong-doing as its focus. But he widens the range of facts relevant to the dialogue, beyond those that relate to the existence and gravity of the wrong, to encompass facts about his response to the wrong-doing qua wrong-doing which, he contends, are a reason for charity towards him.

49 Op. cit. note $24,385-7$. 


\section{John Tasioulas}

The second observation is this. Antecedent repentance is a ground for mercy partly because the hoped-for consequence of punishment is repentance. Now, of course, from the perspective of justice, repentance is to be achieved through undergoing a punishment that is deserved given the gravity of the offence. So understood, antecedent repentance cuts no ice with justice: the deserved punishment remains the same, and as we saw earlier, it is indicative of already repentant offenders that they acknowledge that they deserve punishment and are typically willing to undergo it without any amelioration taking account of their repentance. But still, there is an unavoidable sense of excess in insisting on the full infliction of deserved hard treatment given that the offender has already repented. This altered condition does not affect what he deserves, nor would we say that the already repentant offender has a right to be punished less severely. But given the structure of the communicative theory, and the fact that it is geared in part to the repentance of the offender, a decent concern with the latter's welfare can justify us in tempering the punishment deserved in order to take account of the charitable reasons furnished by his repentance.

Repentance as a ground for mercy, which I claim is integral to the communicative theory of punishment, can be helpfully distinguished from a number of other grounds for leniency (i.e. desisting entirely from punishment or punishing less than the offender deserves), which are not integral to the theory. One is the situation where the offender, subsequent to the offence, is no longer a responsible moral agent, e.g. where he suffers from some severe psychological disorder. Although responsible for the wrong, he is no longer accountable for it. Here, a condition for the communicative process to get a foothold does not obtain, and the offender is exempted from its operation. Something similar can be said about cases where the offender undergoes a sufficiently radical personality change, e.g. a process of brainwashing and total memory loss, which turns him into a different person from the one who committed the original offence. Here again, the communicative theory fails to get any traction. Unlike these cases, the already repentant offender can be held responsible for his prior wrongdoing, and so is appropriately subject to condemnation. Another case in which leniency might be warranted, but which again does not fit into the structure of the theory, is where an offender is treated lightly out of gratitude for past accomplishments (e.g. heroism in military combat) or else in anticipation of some socially valuable contribution he is poised to make, but which the infliction 


\section{Punishment and Repentance}

of punishment on him would threaten to derail (e.g. the discovery of a cure for cancer). These are considerations extraneous to the communicative logic of punishment, and the key reason for this is that they do not have the requisite connection to the wrong-doing. Nor are they grounds for mercy (as opposed to leniency), since their focus is not primarily on the alleviation of the wrong-doer's plight but rather on the honouring of a previous relationship or the advancement of the social good.

Finally, to illustrate antecedent repentance's status as a consideration internal to the communicative theory, let me contrast it with something that is manifestly extraneous to that theory: the notion of mercy elaborated by Claudia Card. For Card, mercy is deserved for what one has suffered, rather than what one has done. It is a reason to punish an offender less severely if he has already suffered more through undeserved misfortune than the just punishment would impose. Mercy represents 'a bit of compensatory good fortune', but it is subject to defeat by the undeserved suffering of those whom the law is designed to protect from crime:

[W] deserve mercy on the basis of what we have suffered, not what we have done, and the suffering need have no connection with the offense. We deserve mercy because of extraordinary severe undeserved misfortunes in our lives, relative to the lives of our victims and the lives of those who depend for protection on enforcement of the rules or laws that we violated. When this condition is met, even an unrepentant offender who does not deserve forgiveness may deserve mercy. ${ }^{50}$

So understood, mercy presupposes both responsibility and wrong-doing on the part of the offender. It is not necessary to contest Card's understanding of desert, which differs markedly from the act-focused interpretation on which I have relied. Nor is it necessary to contest the idea that the compensation for undeserved misfortune represents a genuine ethical consideration. I simply contend that, unlike antecedent repentance, her conception of mercy clearly does not fit within the communicative framework of punishment elaborated so far.

Three reasons can be offered for this claim. First, the communicative focus on the offender's wrong-doing is overtaken by a concern with 'cosmic compensation for inequalities in undeserved

50 C. Card, The Atrocity Paradigm: A Theory of Evil (Oxford: OUP, 2002), 192. 


\section{John Tasioulas}

misfortune' ${ }^{51}$ The latter reflects an egalitarian constraint on the distribution of undeserved misfortune among all humankind. Second, the grounds for mercy need have no special connection with the wrong-doing: they simply represent a form of undeserved misfortune to be set against the just punishment and the similar misfortunes of others. Take two unrelated events in an offender's life: the wrong he commits when, as an adult, he embezzles money from a pension fund, and the great suffering he experienced as a young child from a serious and prolonged illness. On Card's view, the youthful misfortune is a ground for punishing the offender less severely for his subsequent crime (albeit one that may be defeated by the suffering risked to future potential victims). Indeed, a sufficiently unlucky offender might commit crimes with relative impunity under this theory; for, as Card says: 'it is not difficult to imagine that some domestic batterers or parents guilty of child abuse or neglect have already suffered (in their own childhoods) more than just punishment could impose' ${ }^{52}$ Third, compensation for undeserved misfortune unrelated to the wrong-doing is also disconnected from any communicative purpose, such as repentance and reconciliation, that punishment subserves. Of course, mercy offers the offender an opportunity to redeem himself, but this is no part of the rationale for showing him mercy. Whether one thinks that compensation for undeserved misfortune is really a consideration of justice, or any kind of ethical consideration, I conclude that it does not fit within the communicative theory. Allowing it to affect the infliction of punishment really would be to bring in an extraneous consideration that disrupts and transcends the logic of our punitive practices.

Antecedent repentance differs from these other cases in being a central consideration within the communicative enterprise aimed at conveying justified censure for wrong-doing, yet also one that retains its autonomy by resisting subsumption under the norm of retributive desert. Conceiving of it as a distinct consideration, yet one internally related to the unifying formal aim of punishment, equips the institution of punishment to communicate to the offender in a more nuanced, and potentially more compassionate, way than any form of communication informed exclusively by unadulterated considerations of retributive desert. It also explains the normative conflict we characteristically experience in such cases by tracing it to disparate concerns that are nonetheless brought

51 Id., 193.

52 Id., 193. 


\section{Punishment and Repentance}

within an overarching deliberative framework by the formal end of punishment: it is a conflict between reasons of desert to punish and reasons of mercy to show leniency when deliberating about the infliction of hard treatment as justified censure for wrong-doing.

Does my argument prove too much? Does it show that there is an analogous case for punishing offenders less than they deserve in cases where we have good reasons to believe that, quite independently of any punishment, they are highly unlikely to re-offend, even if they have not repented of their wrong? Consider, for example, a petty thief whom we can confidently predict will not resume his life of crime because he has just won first prize in the National Lottery. Now, it may be that such considerations should sometimes influence sentencing, insofar as they may be relevant in determining how much to punish within a range of punishments of varying severity, any of which might be imposed as deserved. Moreover, it could be conceded that the justification for punishing may be less strong in such a case than one in which a significant prevention pay-off is also in the offing. But could 'antecedent prevention', so to speak, justify punishing offenders less than they deserve? Not, I think, within the structure of the communicative theory. And here the contrast with repentance is instructive. The 'already prevented' offender's reasons for not re-offending do not bear a suitable connection to the communicative purposes of punishment; unlike repentance, they do not constitute the appropriate response to the wrong-doing in its nature as wrongful. To temper deserved punishment in the light of independentlycaused deterrence threatens to connive at the non-ideal reasons that discourage the offender from future criminality in a way that is subversive of the communicative ends of punishment.

\section{Conclusion}

There is a propensity in our culture to conceive of mercy in supra-ethical terms, as something that disrupts and transcends mundane ethical concerns, a propensity partly explained by the historical associations of the concept with religion. Retributive justice, on the other hand, perhaps more than any other aspect of our ethical thought, is taken to belong to the vale of tears that is the lot of flawed and vulnerable human beings. In his notebooks, Wittgenstein gave forceful expression to the supposed incongruity between these two concepts: 


\section{John Tasioulas}

'Out of his goodness he has chosen them and he will punish you' makes no sense. The two halves of the proposition belong to different ways of looking at things. The second half is ethical, the first not. And taken together with the first, the second is absurd. ${ }^{53}$

I hope to have shown, by contrast, that mercy on the grounds of repentance is not only an ethical consideration (stemming from charity rather than justice, the compassion we rightly feel towards an offender qua wrong-doer facing a deserved punishment, given certain other facts about him), but also one intimately related to retributive desert within the framework of the communicative theory. In this way, both justice and charity-Locke's two 'great maxims' - can find an integral place in the institution that is perhaps the most dramatic manifestation of the state's coercive power. ${ }^{54}$

Corpus Christi College, Oxford

53 L. Wittgenstein, Culture and Value tr. P. Winch (Oxford: Blackwell, 1980), 81

54 I have benefited greatly from presenting previous versions of this article to departmental seminars at St. Andrews, Stirling, Essex, Hertfordshire and to the Oxford Legal Philosophy Colloquium and the Cambridge Moral Sciences Club. I am grateful to Robert Audi, James Griffin, Andrew von Hirsch, Grant Lamond and David Wood for helpful written comments and friendly disagreement. My thanks are also owed to the Arts and Humanities Research Board for a research leave award allowing me to pursue work on punishment and to the Menzies Centre for Australian Studies for a Bicentennial Fellowship that enabled me to spend three stimulating months at the Centre for Applied Philosophy and Public Ethics at the University of Melbourne. 